\title{
Allergen recognition by innate immune cells: critical role of dendritic and epithelial cells
}

\section{Fabián Salazar and Amir M. Ghaemmaghami *}

Division of Immunology, Faculty of Medicine and Health Sciences, The University of Nottingham, Nottingham, UK

\section{Edited by:}

Christiane Hilger, Centre de

Recherche Public de la Santé,

Luxembourg

Reviewed by:

María Marcela Barrio, Fundación

Cáncer, Argentina

François Hentges, Centre de

Recherche Public de la Santé,

Luxembourg

*Correspondence:

Amir M. Ghaemmaghami, Division of Immunology, West Block, A Floor,

Queen's Medical Centre, The

University of Nottingham, Nottingham

NG7 2UH, UK

e-mail: amg@nottingham.ac.uk
Allergy is an exacerbated response of the immune system against non-self-proteins called allergens and is typically characterized by biased type-2 T helper cell and deleterious $\operatorname{lgE}$ mediated immune responses. The allergic cascade starts with the recognition of allergens by antigen presenting cells, mainly dendritic cells (DCs), leading to Th2 polarization, switching to IgE production by B cells, culminating in mast cell sensitization and triggering. DCs have been demonstrated to play a crucial role in orchestrating allergic diseases. Using different C-type lectin receptors DCs are able to recognize and internalize a number of allergens from diverse sources leading to sensitization. Furthermore, there is increasing evidence highlighting the role of epithelial cells in triggering and modulating immune responses to allergens. As well as providing a physical barrier, epithelial cells can interact with allergens and influence DCs behavior through the release of a number of Th2 promoting cytokines. In this review we will summarize current understanding of how allergens are recognized by DCs and epithelial cells and what are the consequences of such interaction in the context of allergic sensitization and downstream events leading to allergic inflammation. Better understanding of the molecular mechanisms of allergen recognition and associated signaling pathways could enable developing more effective therapeutic strategies that target the initial steps of allergic sensitization hence hindering development or progression of allergic diseases.

Keywords: dendritic cell, epithelial cell, asthma, allergy, type-I hypersensitivity, house dust mite, pattern recognition receptor, TSLP

\section{INTRODUCTION}

Asthma is a chronic disease of the lung characterized by inflammation and airway hyper-responsiveness. Allergic asthma is probably the most common form of asthma and is classified as a type-I hypersensitivity reaction. Most pathologies that are associated with allergic asthma are the consequence of an exacerbated immune response to specific proteins known as allergens in genetically susceptible individuals $(1,2)$. An allergic reaction is characterized by the synthesis of allergen-specific immunoglobulin of the IgE class and Th2 cytokines (e.g., IL-4, IL-5, and IL-13), which lead to recruitment and sensitization of effector cells such as eosinophils, basophils, and mast cells $(1,3)$. During allergen re-exposure, the crosslinking of IgE molecules bounded to highaffinity $F \subset \varepsilon$ receptors $(F \subset \varepsilon R)$ on the surface of mast cells and basophils results in an immediate release of the soluble mediators,

\footnotetext{
Abbreviations: AEC, airway epithelial cell; APC, antigen presenting cell; CLR, Ctype lectin receptor; CRD, carbohydrate recognition domain; DC, dendritic cell; DC-SIGN, dendritic cell-specific intracellular adhesion molecule 3-grabbing nonintegrin; Fc\&R, Fc\& receptor; GM-CSF, granulocyte macrophage colony-stimulating factor; HDM, house dust mite; IDO, indoleamine 2,3 dioxygenase; LPS, lipopolysaccharide; MR, mannose receptor; NF- $\kappa B$, nuclear factor $\kappa B$; PAMP, pathogenassociated molecular pattern; PAR, protease activated receptor, PRR, pattern recognition receptor; TGF- $\beta$, transforming growth factor- $\beta$; TLR, toll-like receptor TNF, tumor necrosis factor; TSLP, thymic stromal lymphopoietin; VEGF, vascular endothelial growth factor.
}

such as histamine, leukotriene, and prostaglandins, which are responsible for the allergic reaction $(1,4)$.

Antigen recognition and uptake by innate immune cells is the first step in the process of antigen presentation that could lead to initiation of adaptive immune responses. Using a diverse set of pattern recognition receptors (PRRs) such as Toll-like receptors (TLRs) and C-type lectin receptors different types of immune and non-immune cells are able to sense conserved motifs on antigens. Dendritic cells (DCs) have been demonstrated to play a pivotal role in this process; however, the molecular mechanisms of how Th2-driven allergic immune responses are initiated and amplified have remained elusive (3-5). Recently, the role of epithelial cells as key modulators of DC behavior has been highlighted $(6,7)$. Specifically, airway epithelial cells (AECs) have been demonstrated to be able to recognize diverse allergens leading to the release of chemokines, cytokines, and danger signals that activate and recruit other immune cells to the site of inflammation $(6,7)$.

In this review, we will discuss the role of dendritic and epithelial cells in allergen recognition and how the cross-talk between DCs and AEC could affect Th2-mediated allergic diseases.

\section{ALLERGEN RECOGNITION BY DENDRITIC CELLS}

Immature DCs reside in the peripheral tissues and can efficiently sample the microenvironment for antigens. Once taken up by DCs such antigens are processed into peptides and appear on the 
surface of DCs in the context of MHC molecules. Antigen bearing DC migrate to the local lymph nodes where through expression of MHCII-peptide complex, cytokines, and co-stimulatory molecules they can stimulate naïve T cells toward distinct effector T cell subsets (e.g., Th1, Th2, Th17) $(8,9)$ or induce tolerance through induction of regulatory $\mathrm{T}$ cells (10), depending on the nature of the antigen and other microenvironmental factors (11). DCs serve as sentinels of the mucosal surfaces, where they constantly sample antigens at the interface between external and internal environments using different PRRs (Figure 1). Even intraepithelial DCs are able to form tight junctions with epithelial cells through expression of proteins like occludin and claudin, which can further facilitate antigen/allergen recognition and uptake by these cells ( 7 , 8). In addition, some allergens can gain access to DCs by disrupting the tight junctions (9-15); different mechanisms of allergen recognition and uptake by DCs will be further described in the following sections.

\section{C-TYPE LECTIN RECEPTORS}

C-type lectin receptors are mainly involved in the recognition of glyco-allergens. Diverse C-type lectin receptors (CLRs), such as dendritic cell-specific intracellular adhesion molecule 3-grabbing non-integrin (DC-SIGN) and mannose receptor (MR) on human DCs have been shown to be able to recognize and internalize allergens.

\section{MANNOSE RECEPTOR}

This type-I integral transmembrane protein is primarily expressed by myeloid cells such as macrophages and DCs $(4,16)$. The extracellular portion of MR consists of three regions: a cysteine-rich domain, a fibronectin type II-like domain, and eight carbohydrate recognition domains (CRDs). Interestingly, DCs from patients with house dust mite (HDM) allergy have been shown to express higher levels of MR and to be more efficient in allergen uptake than DCs from non-atopic donors (17). More recently, it was reported that bronchoalveolar lavage fluid from patients with asthma and/or allergic rhinitis contains higher numbers of MR expressing myeloid-DCs compared to healthy controls (18). In terms of allergen uptake, in vitro studies have found that MR expressed on human monocyte-derived DCs is the main receptor for major allergens from HDM $(\operatorname{Der} p 1), \operatorname{dog}(\operatorname{Can} f 1)$, cockroach (Bla g 2), peanut (Ara h 1), and cat (Fel d 1) (19, 20). Similar studies have also highlighted MR's role in allergen-induced Th2 cell differentiation where $\mathrm{MR}$-deficient $\left(\mathrm{MR}^{-}\right)$, as opposed to $\mathrm{MR}$ expressing $(\mathrm{MR}+)$, DCs failed to induce Th2 cell differentiation in response to Der $\mathrm{p} 1$ in DC-T cell co-cultures from HDM atopic individuals. The bias toward Th1 cell polarization by $\mathrm{MR}^{-} \mathrm{DCs}$ was shown to be partially mediated through the up-regulation of indoleamine 2,3-dioxygenase (IDO) activity in DCs (19). IDO is an enzyme that participates in tryptophan metabolism and is involved in many immune-regulatory processes in health and

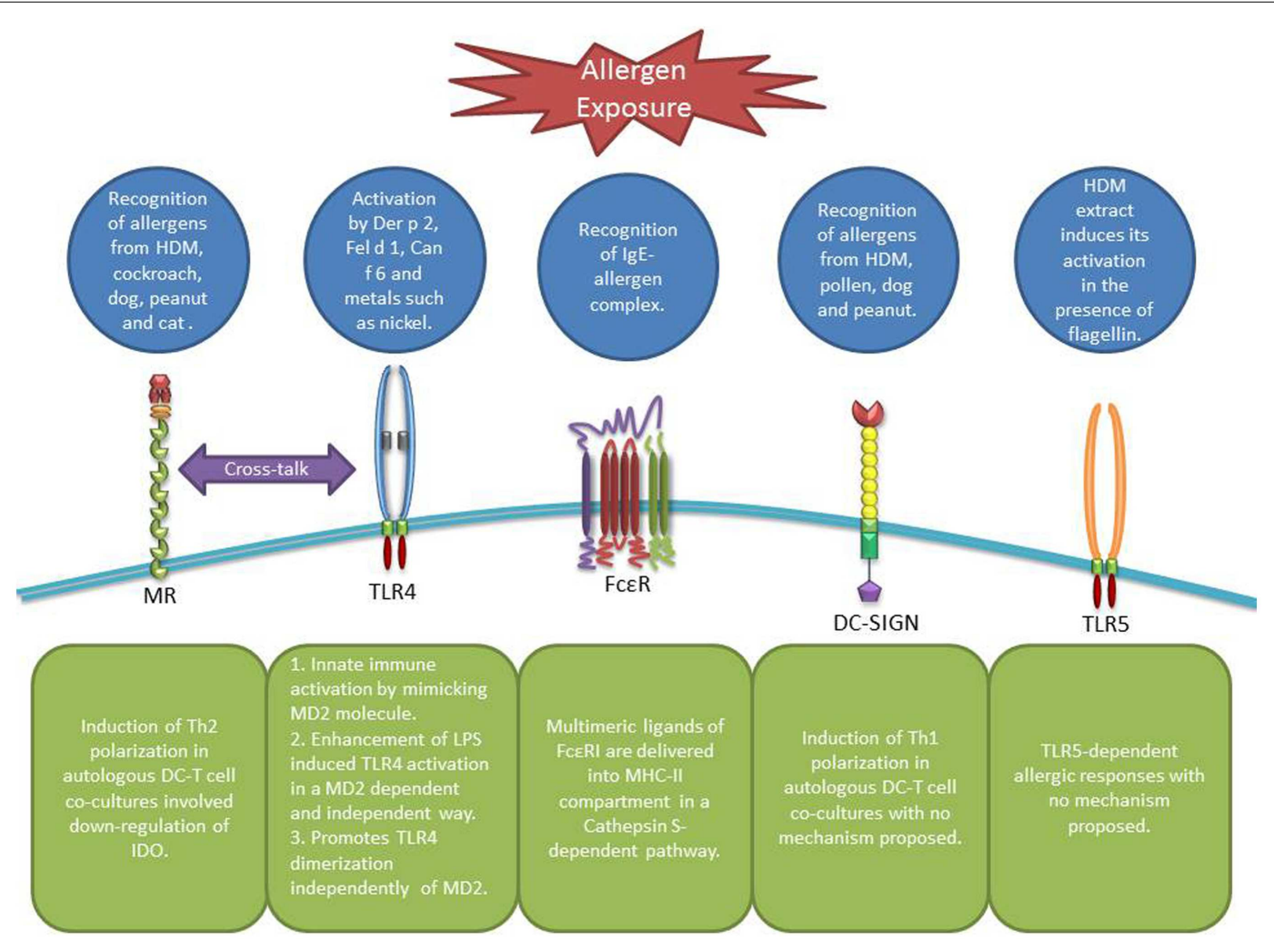

FIGURE 1 | Receptors involved in allergen recognition and uptake by DCs. MR can recognize allergens from diverse sources leading to Th2 polarization and IDO down-regulation in DCs involving a possible cross-talk with TLR4 (19). TLR4 itself can be activated by airborne allergens and diverse metals in an
MD2 dependent or independent way $333,35-37)$. FceR facilitate allergen uptake through the recognition of the IgE-allergen complex $(41,46)$. DC-SIGN can recognize diverse allergens as well, however, leading to a Th1 polarization. Finally, TLR5 can be activated by HDM extracts containing flagellin (34). 
disease $(21,22)$. Further studies by the same group showed that MR recognition of major cat allergen Feld 1 mediated the production of specific IgE and IgG1 antibodies in a mouse model of allergy (20). Other studies have shown that omega-1, a glycosylated T2 ribonuclease secreted by Schistosoma mansoni eggs, is recognized and internalized by DCs through MR and subsequently interferes with proteins synthesis and conditions DCs for Th2 priming (23). Collectively these data highlight MR's role in allergen recognition and promotion of Th2-mediated immune responses.

\section{DENDRITIC CELL-SPECIFIC INTRACELLULAR ADHESION MOLECULE 3-GRABBING NON-INTEGRIN}

Dendritic cell-specific intracellular adhesion molecule 3-grabbing non-integrin is a type-II integral transmembrane protein that consists of four regions: a CRD, a hinge domain, and a transmembrane region connected to a cytoplasmic signaling domain $(4,24)$. DCSIGN is mainly expressed by antigen presenting cells (APCs) and has been demonstrated to participate in the recognition of allergens from different sources, such as peanut, HDM, pollen, and dog (25-27). In vitro studies have been shown that DC-SIGN recognition and uptake of Der $\mathrm{p} 1$ induces Th1 cell differentiation. On the contrary, DC-SIGN deficient DCs bias the response toward a Th2 profile (27). This is opposite to previous observations in $\mathrm{MR}^{-}$ DCs which seem to support Th1 differentiation (19). Interestingly, it has also been shown that Der p 1, using its enzymatic activity, can cleave (28) and induce the down-regulation (29) of cell surface DC-SIGN but not MR (28). In this context, we have previously proposed that the Th1/Th2 balance in response to allergen exposure can be determined by the cross-talk between these receptors and the level of their expression on DCs $(4,27)$. Accordingly, it is important to note that DCs from asthmatic patients show lower expression of DC-SIGN (29), which is in contrast to the high levels of MR expression reported in atopic individuals $(17,18)$.

\section{TOLL-LIKE RECEPTORS}

The TLRs are type-I integral membrane receptors, each with an $\mathrm{N}$-terminal ligand recognition domain constructed of tandem copies of a leucine-rich repeat motif, a single transmembrane helix, which participates in nucleic acid pathogen-associated molecular patterns (PAMPs) recognition, and a C-terminal cytoplasmic signaling domain known as Toll IL-1 receptor domain (30). There are more than 10 different TLRs identified in humans so far (31), with some of them being involved in allergen recognition or pathways that induces allergic responses. Within this context, mainly three different mechanisms have been proposed. Der $\mathrm{p} 2$, a major allergen from HDM with lipid-binding activity, has been shown to induce signaling through TLR2 (32) and TLR4 (33) depending on the cell type involved. Due to its high homology with MD2, which participates in the recognition of lipopolysaccharide (LPS) by TLR4, Der p 2 forms a complex with TLR4 that signals similarly to MD2/TLR4 complex inducing innate immune activation (33). In addition, HDM extracts contaminated with flagellin can induce TLR5-dependent allergic responses in mice, however, the mechanism is still unclear (34). The second mechanism involves sensitization by nickel, which may not be relevant in the context of airway sensitization but highlights the importance of TLR4 on DCs in allergic reactions. Nickel and other bivalent metals such as cobalt induce a lipid-independent activation of TLR4, which is dependent on the presence of two histidine residues, promoting TLR4 dimerization and subsequent receptor activation independently of MD2 $(35,36)$. Finally, the last mechanism involves allergens such as Fel $\mathrm{d} 1$ and Can $\mathrm{f} 6$ that belong to lipocalin family and cause enhanced LPS-induced TLR4 activation in an MD2 dependent and independent manner respectively (37).

\section{HIGH-AFFINITY IGE RECEPTOR}

FceRI is a multimeric cell surface receptor that binds IgE with high-affinity. In humans, this receptor can be expressed by mast cells, basophils, eosinophils, platelets, monocytes, and DCs; however, in the last four cell types it adopts a trimeric $(\alpha \gamma 2)$ structure instead of the classical tetrameric $(\alpha \beta \gamma 2)$ structure (38-43). It has been previously suggested that cell-bound IgE participates in the presentation of aero-allergens by Langerhans cells (44). In addition, the presence of FceRI on Langerhans cells maximizes antigen uptake via specific IgE and subsequent presentation to T cells (45). In monocytes and peripheral blood DCs, FceRI has been shown to mediate IgE-dependent allergen presentation (41, 46). Further studies in DCs demonstrated that multimeric ligands of FceRI are delivered into a major histocompatibility complex class II compartment in a Cathepsin S-dependent pathway (47). In vivo experiments with a transgenic mouse model with humanlike FceRI expression in DCs showed that after allergen capture DCs instructed naïve $\mathrm{T}$ cells to differentiate into allergen-specific Th2 cells at the site of allergen exposure (48). Taking into account the fact that higher expression of FceRI has been detected in atopic individuals $(40,42)$, this can lower the atopic individual's threshold to mount allergen-specific $\mathrm{T}$ cell responses. All this highlights the fact that the high-affinity IgE receptor could play an important role in capturing allergens by DCs and subsequent presentation to $\mathrm{T}$ cell particularly in previously sensitized individuals with high levels of specific IgE; however, the precise role of IgE receptors and the role of other stimulatory and inhibitory $\mathrm{Fc}$ receptors $(49,50)$ in allergen presentation still need to be fully understood.

\section{ALLERGEN RECOGNITION BY EPITHELIAL CELLS}

Airway epithelial cells constitute the first line of defense against pathogens and allergens by not only forming a physical barrier, but also through expressing a wide range of PRR, such as TLRs, CLRs, and protease activated receptor (PARs) (Figure 2). These receptors enable AECs to recognize microbial motifs and environmental allergens which lead to a cascade of events culminating in the release of cytokines, chemokine ligands, and danger signals which recruit and activate other immune cells.

\section{PROTEASE ACTIVATED RECEPTORS}

Protease activated receptors are G-protein coupled receptors characterized by a self-activation mechanism following proteolytic cleavage of their extracellular $\mathrm{N}$-terminal domain. There are four PAR members identified to date. PAR-1,-3,-4 respond to the protease thrombin, expressed primarily by cells in the vasculature; and are mainly involved in homeostasis and thrombosis. Conversely, PAR-2 is activated by trypsin-like serine proteases but not by trypsin and can be found in airways, vascular, skin, and intestinal cells, and mediates proliferative and inflammatory responses 


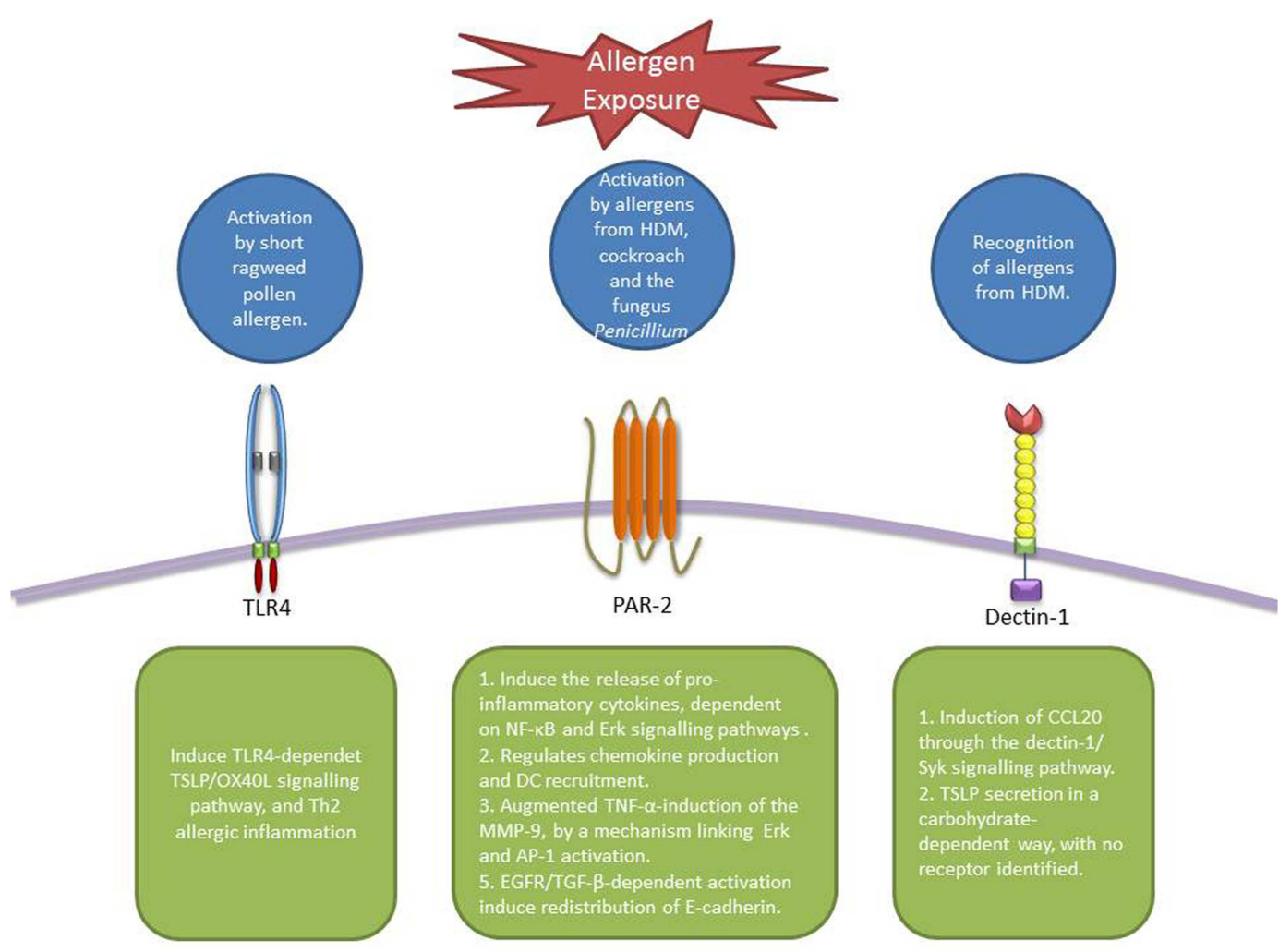

FIGURE 2 | Receptors involved in allergen recognition and uptake by AECs. TLR4 can be activated by pollen allergens and activate TSLP-OX40L signaling pathway (88). PAR-2 is activated by different allergens from HDM, cockroach, and fungus inducing the production of cytokines and chemokines that modulate DC behavior $(60,61,64-67)$. Dectin- 1 is able to recognize allergens from HDM and induce the secretion of CCL20 (90). In addition, the secretion of TSLP induced by Der $p 1$ in AECs is thought to be carbohydrate-dependent, however, no receptor has been identified (92). linked to tissue damage $(51,52)$. In addition, endothelial cells, epithelial cells, fibroblasts, and immune cells such as lymphocytes, monocytes, mast cells, neutrophils, eosinophils, macrophages, and DCs have been shown to express functional PAR-2 $(53,54)$. Due to its ability to respond to serine proteases, proteolytic allergens from diverse sources such as HDM, cockroach, pollen, or mold can act as exogenous activators of PAR-2 with implications in allergy and asthma.

Different cysteine and serine proteases from HDM, pollen, and the fungus Penicillium have been shown to increase epithelial permeability and disrupt the tight junctions by mainly targeting the transmembrane adhesion proteins occludin and zonula occludens-1 (9-15). In addition, it has been demonstrated that allergen-induced cytokine production, cell detachment and morphological changes in AECs is largely dependent on allergens' protease activity $(13,55-58)$. Protease-dependant induction of IL25 and thymic stromal lymphopoietin (TSLP) have been shown to be mediated by Erk and p38 MAPK pathways (58). More recently, it was demonstrated, in an in vivo model, that IL-33 also contributes to protease-dependent allergic airway inflammation (59).

Main allergens from HDM can activate PAR-2 and induce the release of pro-inflammatory cytokines $(60,61)$. However, there is some contradictory results showing that Der $\mathrm{p}$ 1-induction of IL8 and IL- 6 is independent of PAR- 2 activation and dependent on nuclear factor $\kappa \mathrm{B}(\mathrm{NF}-\kappa \mathrm{B})$ and Erk signaling pathways $(62,63)$. In the case of allergens from the German cockroach and the fungus Penicillium, this effect has been demonstrated to be mediated by the activation of Erk $(64,65)$. In an in vivo model of allergy, only when the allergens are administered through the mucosa, cockroach proteases regulate chemokine production and DC recruitment in a PAR-2-dependent way $(66,67)$. Furthermore, it was demonstrated that cockroach proteases augmented tumor necrosis factor (TNF)- $\alpha$-induction of the matrix metalloproteinases- 9 , an enzyme that has been implicated in the pathogenesis of bronchial asthma $(68,69)$, by a mechanism linking PAR-2, Erk, and AP-1 activation (70). More recently, PAR-2-mediated allergic sensitization was shown to be associated with TNF signaling pathways (71).

In addition to the proteolytic activity of some allergens, one of the main soluble mediators that accounts for the increase in epithelial permeability is the vascular endothelial growth factor (VEGF). It has been shown that extract from cockroach increases bronchial airway epithelial permeability by inducing the release of VEGF (72). Besides, HDM extract can induce the secretion of VEGF by human pulmonary epithelial cells (73). Recently, it was demonstrated that HDM-induced redistribution of E-cadherin was mediated via epidermal growth factor receptor-dependent activation of PAR- 2 and transforming growth factor- $\beta$ (TGF- $\beta$ ) enhanced this signaling (74). Nevertheless, not only PAR-2 is directly involved 
in allergen-mediated cytokine production, it has also been shown that IL- 8 production by AECs in response to allergens from the fungus Penicillium is dependent on PAR-1 and PAR-2 via activation of ERK1/2 (65). In addition, proteases from different fungal allergens induce the release of pro-inflammatory cytokines from human nasal polyp epithelial cells, leading to eosinophil and neutrophil migration, in a mechanism that could involve PAR-2 and PAR-3 (75).

\section{TOLL-LIKE RECEPTOR-4}

As previously described, TLRs are widely expressed by both APCs and epithelial cells and recognize conserved microbial structures and as such play a key role in controlling adaptive immune responses. LPS is recognized by TLR 4 with the participation of the accessory proteins including CD14, LPS binding protein, and MD2. This leads to the recruitment of the signaling adapter protein MyD88, the activation of the transcription NF- $\kappa \mathrm{B}$ among others, and the expression of pro-inflammatory cytokines (76). TLR4 (77-80), MyD88 (79, 81, 82), and NF- $\kappa$ B (83-86) have been shown to be crucial in the elicitation of allergic Th2 immune responses. Different studies using knock-out mice have demonstrated the importance of TLR4 expression in both hematopoietic radiosensitive and structural radioresistant cells in the induction of TLR4-dependent Th2 responses to intranasal allergens in the presence of endotoxin (77-80). In addition, it has been shown that the LPS dosage is crucial in driving either Th1 or Th2 responses, with lower levels of LPS inducing Th2 responses to inhaled allergens in a mouse model of allergic sensitization (87). Recently, it was shown that short ragweed pollen acts as a TLR4 agonist, initiating TLR4-dependet TSLP/OX40L signaling pathway, triggering Th2 allergic inflammation (88).

\section{C-TYPE LECTIN RECEPTORS}

C-Type Lectin Receptors are receptors that recognize oligosaccharide moieties among other molecular patterns on antigens including allergens (89). CLR's role in allergen recognition and uptake by DCs is well established (4); moreover, they have also been shown to participate in allergen recognition by AECs. It was demonstrated that HDM induction of CCL20 by AECs was not protease or TLR4/2 dependant; however, it was mediated by $\beta$-glycan moieties within HDM extract. This effect was specific for HDM because other allergens, such as cockroach and ragweed, failed to induce this response (90). The authors suggest the involvement of the dectin-1/Syk signaling pathway, since Syk inhibition abrogated the HDM-induced CCL20 production (91). More recently, our group demonstrated that TSLP secretion by AECs upon stimulation with Der p 1 was at least partly carbohydratedependent. In addition, DC uptake of deglycosylated Der p 1 was considerably decreased compared with its natural (glycosylated) counterpart, indicating that glycosylation of allergens plays a crucial role in their recognition by immune and non-immune cells (92).

\section{CROSS-TALK BETWEEN DENDRITIC AND EPITHELIAL CELLS}

Due to their strategic location at the interface of external-internal environments, AECs are able to modulate and coordinate immune responses. Ample data have shown that the cross-talk between DCs and AECs is crucial in driving allergen-induced Th2 responses (6, 7). As previously described, the ligation of different PRR on AECs results in the secretion of chemokines (93-95), that attract DCs, and cytokines that induce DC maturation and activation. However, there are some contradictory results indicating that inducible signals driven by LPS in non-hematopoietic tissues such as AECs do not play an essential role in DCs activation (96). On the other hand other studies have demonstrated that AECs can induce DC maturation after LPS inhalation (81). Nevertheless a range of cytokines including TSLP, IL-33, IL-25, IL-1 $\beta$, and granulocyte macrophage colony-stimulating factor (GM-CSF) are known to be secreted by AECs after allergen challenge $(6,7)$ which are able to modulate DCs function (Figure 3). Here we focus on TSLP as a key cytokine in initiation and maintenance of allergic responses.

\section{ROLE OF TSLP}

Thymic stromal lymphopoietin is a 140 -amino acid four-helixbundle cytokine that belongs to the IL-2 family of cytokines. This cytokine is mainly produced by AECs and is able to modulate DC by binding to its receptor complex composed by the TSLP receptor (TSLPR) and the IL-7 receptor (IL-7R) (97). This induces the production of Th2-attracting chemokines such as CCL22 and CCL17, and primes naïve T cells to produce IL-5, IL- 4 , TNF- $\alpha$, IL-13, whereas down-regulate IL-10 and $\operatorname{IFN}-\gamma(98,99)$ even in the absence of DCs in an IL-4 dependant way (100). TSLP induces the expression of OX40L in DCs which in turn has been shown to trigger Th2 cell polarization in the absence of IL-12 (101). Conversely, TSLP is also able to induce IL-12 secretion after CD40 ligation in DCs however still maintaining its Th2-polarizing effect (102). Furthermore, DCs activated with TSLP were able to induce the expansion of Th2 memory cells and help to maintain their phenotype (103).

Human epithelial cells can produce TSLP in response to diverse stimuli, such as microbial products, physical injury, ambient particulate matter, protease allergens, and either pro-inflammatory or Th2-polarizing cytokines (58, 104-108). Protease allergens induce TSLP in a PAR-2-dependent way (109) with the involving of MAPK signaling pathway (58) however inflammatory cytokines induction of TSLP is NF- $\kappa \mathrm{B}$ signaling dependent $(104,106)$. In addition to DCs, TSLP can also activate mast cells and CD34+ blood hematopoietic progenitor cells to produce Th2 cytokines and in that way induce the innate phase of allergic immune responses $(105,110)$. Finally, TSLP can interfere with regulatory $\mathrm{T}$ cell development impairing the balance between tolerance and inflammation (111). Keratinocytes too can secrete functional TSLP after stimulation with pro-inflammatory or Th2-driven cytokines, and induces DC activation in human skin lesions of atopic dermatitis (112). Recently, it was demonstrated that DCs can also produce TSLP in response to TLR stimulation. Moreover, interestingly DCs from mice challenged with HDM extract express higher mRNA levels of TSLP than epithelial cells (113).

In vivo experiments have shown that TSLPR knock-out mice exhibited strong Th1 responses while Th2 responses were impaired and they failed to develop an inflammatory response to allergen challenge to lung (114) or skin (115). In addition, skin and lung over-expression of TSLP induces atopic dermatitis (116) and airway inflammation respectively (117). In an experimental model of 


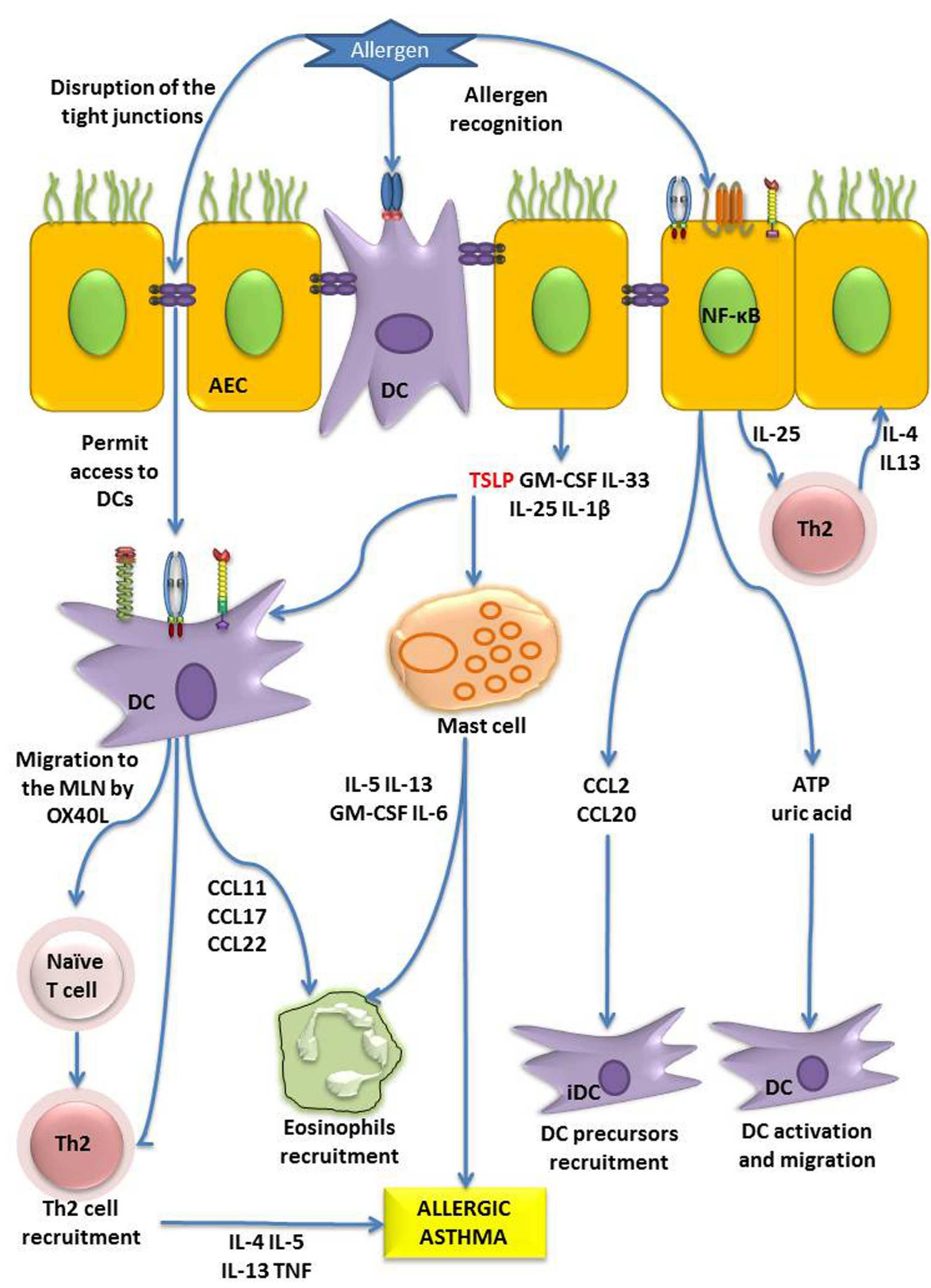

FIGURE 3 | Role of AECs in allergen sensitization. AECs can directly recognize allergens by PARs, TLRs or CLRs, and through NF- $\mathrm{B}$ signaling, they induce the production of the cytokines (TSLP, GM-CSF, IL-33, IL-25, IL-1 $\beta$ ), chemokine ligands (CCL2, CCL20), and danger signals (adenosine triphosphate, uric acid). TSLP has diverse effects on DCs and mast cells, which in absence of the cytokine IL-12 can lead to recruitment of Th2 cells and (eosinophils, Th2 polarization, and the onset of allergy or allergic asthma. Moreover, IL-25 can activate Th2 cells to produce pro-allergenic cytokines. On the other hand, DCs are able to form tight junction with AECs, and allergen can digest the tight junction and both phenomena contribute to facilitate the allergen sensitization process $(6,7)$. allergic conjunctivitis it was demonstrated that after topical allergen challenge mucosal epithelial cells produce high levels of TSLP compared with controls leading to induction of allergic inflammation through the TSLP-OX40L signaling pathway (118). More recently, it was shown that the soluble TSLPS antagonist, comprised of the extracellular domain of the murine TSLPR and an IgG2a Fc tail, reduced the severity of airway inflammation by regulating DC function (119).
Furthermore, it has been demonstrated that TSLP and Th2-attracting chemokines are increased in airways of asthmatic subjects compared with normal controls (120). In addition, different studies have shown an association between genetic polymorphisms in the human IL-7R $\alpha$ chain and TSLP genes with allergy, allergic rhinitis, and bronchial asthma further highlighting a possible link between these proteins and allergy (121-123). 


\section{CONCLUSION}

Dendritic cells are professional APCs and sentinels of the immune system that efficiently sample allergens in the airways leading to a cascade of events that culminates in the induction of Th2 type immune responses. DCs are able to recognize and internalize allergens from diverse sources through expression of a plethora of receptors such as CLRs, TLRs, and FcER. Recently, the role of AECs as key players in the modulation and induction of DCs in the airways has been highlighted. Like DCs, AECs are able to recognize allergens through several PRRs including PARs, CLRs, and TLRs. This further leads to the production of different cytokines, chemokines, and danger signals with the ability to initiate and propagate immune responses to allergens. Allergens have diverse molecular features such as specific oligosaccharide moieties, protease activity, lipid-binding properties, among others that can facilitate their recognition by immune and non-immune cells and contributes to their "allergenicity." Better understanding of the molecular basis of early events at the interface of allergens and their receptors and the key soluble mediators/signaling pathways involved could lead to development of more effective therapeutic strategies for allergic diseases including allergic asthma. For instance, due to the contribution of TLRs and CLRs in the recognition of allergen by both DCs and AECs, agonist and antagonists to those receptors may provide new therapeutic targets to modulate allergic responses. In addition, different studies have highlighted the role of sugar moieties on allergens in their recognition and internalization by immune cells. Accordingly, different "glycoforms" of allergens with immunoregulatory properties could be developed and used in allergen-specific immunotherapy strategies. Finally, diverse intracellular and extracellular molecules have been implicated in the process of allergen recognition and sensitization. Further studies to decipher these mechanisms could pave the way for the rational design of more effective therapeutic entities for the treatment of allergic diseases.

\section{ACKNOWLEDGMENTS}

F. Salazar is a recipient of a PhD scholarship from the National Commission for Scientific and Technological Research (CONICYT), Chile.

\section{REFERENCES}

1. Paul WE, Zhu J. How are $\mathrm{T}(\mathrm{H}) 2$-type immune responses initiated and amplified? Nat Rev Immunol (2010) 10(4):225-35. doi:10.1038/nri2735

2. Karp CL. Guilt by intimate association: what makes an allergen an allergen? J Allergy Clin Immunol (2010) 125(5):955-60. doi:10.1016/j.jaci.2010.03.002

3. Gill MA. The role of dendritic cells in asthma. J Allergy Clin Immunol (2012) 129(4):889-901. doi:10.1016/j.jaci.2012.02.028

4. Salazar F, Sewell HF, Shakib F, Ghaemmaghami AM. The role of lectins in allergic sensitization and allergic disease. J Allergy Clin Immunol (2013) 132(1):27-36. doi:10.1016/j.jaci.2013.02.001

5. Shakib F, Ghaemmaghami AM, Sewell HF. The molecular basis of allergenicity. Trends Immunol (2008) 29(12):633-42. doi:10.1016/j.it.2008.08.007

6. Willart M, Hammad H. Lung dendritic cell-epithelial cell crosstalk in Th2 responses to allergens. Curr Opin Immunol (2011) 23(6):772-7. doi:10.1016/j. coi.2011.09.008

7. Hammad H, Lambrecht BN. Dendritic cells and epithelial cells: linking innate and adaptive immunity in asthma. Nat Rev Immunol (2008) 8(3):193-204. doi:10.1038/nri2275

8. Sung SS, Fu SM, Rose CE Jr, Gaskin F, Ju ST, Beaty SR. A major lung CD103 (alphaE)-beta7 integrin-positive epithelial dendritic cell population expressing Langerin and tight junction proteins. J Immunol (2006) 176(4): 2161-72.

9. Herbert CA, King CM, Ring PC, Holgate ST, Stewart GA, Thompson PJ, et al. Augmentation of permeability in the bronchial epithelium by the house dust mite allergen Der p1. Am J Respir Cell Mol Biol (1995) 12(4):369-78. doi:10.1165/ajrcmb.12.4.7695916

10. Roche N, Chinet TC, Belouchi NE, Julie C, Huchon GJ. Dermatophagoides pteronyssinus and bioelectric properties of airway epithelium: role of cysteine proteases. Eur Respir J (2000) 16(2):309-15. doi:10.1034/j.1399-3003.2000. $16 \mathrm{~b} 20 . \mathrm{x}$

11. Wan H, Winton HL, Soeller C, Gruenert DC, Thompson PJ, Cannell MB, et al. Quantitative structural and biochemical analyses of tight junction dynamics following exposure of epithelial cells to house dust mite allergen Der $\mathrm{p}$ 1. Clin Exp Allergy (2000) 30(5):685-98. doi:10.1046/j.1365-2222.2000.00820.x

12. Wan H, Winton HL, Soeller C, Taylor GW, Gruenert DC, Thompson PJ, et al. The transmembrane protein occludin of epithelial tight junctions is a functional target for serine peptidases from faecal pellets of Dermatophagoides pteronyssinus. Clin Exp Allergy (2001) 31(2):279-94. doi:10.1046/j.1365-2222. 2001.00970.x

13. Tai HY, Tam MF, Chou H, Peng HJ, Su SN, Perng DW, et al. Pen ch 13 allergen induces secretion of mediators and degradation of occludin protein of human lung epithelial cells. Allergy (2006) 61(3):382-8. doi:10.1111/j.13989995.2005.00958.x

14. Runswick S, Mitchell T, Davies P, Robinson C, Garrod DR. Pollen proteolytic enzymes degrade tight junctions. Respirology (2007) 12(6):834-42. doi:10.1111/j.1440-1843.2007.01175.x

15. Vinhas R, Cortes L, Cardoso I, Mendes VM, Manadas B, Todo-Bom A, et al. Pollen proteases compromise the airway epithelial barrier through degradation of transmembrane adhesion proteins and lung bioactive peptides. Allergy (2011) 66(8):1088-98. doi:10.1111/j.1398-9995.2011.02598.x

16. Taylor PR, Gordon S, Martinez-Pomares L. The mannose receptor: linking homeostasis and immunity through sugar recognition. Trends Immunol (2005) 26(2):104-10. doi:10.1016/j.it.2004.12.001

17. Deslee G, Charbonnier AS, Hammad H, Angyalosi G, Tillie-Leblond I, Mantovani A, et al. Involvement of the mannose receptor in the uptake of Der p 1, a major mite allergen, by human dendritic cells. J Allergy Clin Immunol (2002) 110(5):763-70. doi:10.1067/mai.2002.129121

18. Kayserova J, Zentsova-Jaresova I, Budinsky V, Rozkova D, Kopecka J, Vernerova E, et al. Selective increase in blood dendritic cell antigen-3-positive dendritic cells in bronchoalveolar lavage fluid in allergic patients. Scand J Immunol (2012) 75(3):305-13. doi:10.1111/j.1365-3083.2011.02649.x

19. Royer PJ, Emara M, Yang C, Al-Ghouleh A, Tighe P, Jones N, et al. The mannose receptor mediates the uptake of diverse native allergens by dendritic cells and determines allergen-induced T cell polarization through modulation of IDO activity. J Immunol (2010) 185(3):1522-31. doi:10.4049/jimmunol.1000774

20. Emara M, Royer PJ, Abbas Z, Sewell HF, Mohamed GG, Singh S, et al. Recognition of the major cat allergen Fel d 1 through the cysteine-rich domain of the mannose receptor determines its allergenicity. J Biol Chem (2011) 286(15):13033-40. doi:10.1074/jbc.M111.220657

21. Munn DH, Mellor AL. Indoleamine 2,3 dioxygenase and metabolic control of immune responses. Trends Immunol (2012) 34(3):137-43. doi:10.1016/j.it. 2012.10.001

22. Orabona C, Pallotta MT, Grohmann U. Different partners, opposite outcomes: a new perspective of IDO's immunobiology. Mol Med (2012) 18(1):834-42. doi:10.2119/molmed.2012.00029

23. Everts B, Hussaarts L, Driessen NN, Meevissen MH, Schramm G, van der Ham AJ, et al. Schistosome-derived omega-1 drives Th2 polarization by suppressing protein synthesis following internalization by the mannose receptor. J Exp Med (2012) 209(10):1753-67. doi:10.1084/jem.20111381

24. Zhou T, Chen Y, Hao L, Zhang Y. DC-SIGN and immunoregulation. Cell Mol Immunol (2006) 3(4):279-83.

25. Shreffler WG, Castro RR, Kucuk ZY, Charlop-Powers Z, Grishina G, Yoo S, et al. The major glycoprotein allergen from Arachis hypogaea, Ara h 1, is a ligand of dendritic cell-specific ICAM-grabbing nonintegrin and acts as a Th2 adjuvant in vitro. J Immunol (2006) 177(6):3677-85.

26. Hsu SC, Chen $\mathrm{CH}$, Tsai SH, Kawasaki H, Hung $\mathrm{CH}$, Chu YT, et al. Functional interaction of common allergens and a C-type lectin receptor, dendritic cell-specific ICAM3-grabbing non-integrin (DC-SIGN), on human 
dendritic cells. J Biol Chem (2010) 285(11):7903-10. doi:10.1074/jbc.M109. 058370

27. Emara M, Royer PJ, Mahdavi J, Shakib F, Ghaemmaghami AM. Retagging identifies dendritic cell-specific intercellular adhesion molecule-3 (ICAM3)grabbing non-integrin (DC-SIGN) protein as a novel receptor for a major allergen from house dust mite. J Biol Chem (2012) 287(8):5756-63. doi:10. 1074/jbc.M111.312520

28. Furmonaviciene R, Ghaemmaghami AM, Boyd SE, Jones NS, Bailey K, Willis $\mathrm{AC}$, et al. The protease allergen Der $\mathrm{p} 1$ cleaves cell surface DC-SIGN and DC-SIGNR: experimental analysis of in silico substrate identification and implications in allergic responses. Clin Exp Allergy (2007) 37(2):231-42. doi:10.1111/j.1365-2222.2007.02651.x

29. Huang HJ, Lin YL, Liu CF, Kao HF, Wang JY. Mite allergen decreases DC-SIGN expression and modulates human dendritic cell differentiation and function in allergic asthma. Mucosal Immunol (2011) 4(5):519-27. doi:10.1038/mi.2011.17

30. Botos I, Segal DM, Davies DR. The structural biology of toll-like receptors. Structure (2011) 19(4):447-59. doi:10.1016/j.str.2011.02.004

31. O'Neill LA, Golenbock D, Bowie AG. The history of toll-like receptors-redefining innate immunity. Nat Rev Immunol (2013) 13(6):453-60. doi:10.1038/ nri3446

32. Chiou YL, Lin CY. Der p2 activates airway smooth muscle cells in a TLR2/MyD88-dependent manner to induce an inflammatory response. J Cell Physiol (2009) 220(2):311-8. doi:10.1002/jcp.21764

33. Trompette A, Divanovic S, Visintin A, Blanchard C, Hegde RS, Madan R, et al. Allergenicity resulting from functional mimicry of a Toll-like receptor complex protein. Nature (2009) 457(7229):585-8. doi:10.1038/nature07548

34. Wilson RH, Maruoka S, Whitehead GS, Foley JF, Flake GP, Sever ML, et al. The toll-like receptor 5 ligand flagellin promotes asthma by priming allergic responses to indoor allergens. Nat Med (2012) 18(11):1705-10. doi:10.1038/nm.2920

35. Schmidt M, Raghavan B, Muller V, Vogl T, Fejer G, Tchaptchet S, et al. Crucial role for human Toll-like receptor 4 in the development of contact allergy to nickel. Nat Immunol (2010) 11(9):814-9. doi:10.1038/ni.1919

36. Raghavan B, Martin SF, Esser PR, Goebeler M, Schmidt M. Metal allergens nickel and cobalt facilitate TLR4 homodimerization independently of MD2. EMBO Rep (2012) 13(12):1109-15. doi:10.1038/embor.2012.155

37. Herre J, Gronlund H, Brooks H, Hopkins L, Waggoner L, Murton B, et al. Allergens as immunomodulatory proteins: the cat dander protein Fel d 1 enhances TLR activation by lipid ligands. J Immunol (2013) 191(4):1529-35. doi:10.4049/jimmunol.1300284

38. Kinet JP. The high-affinity IgE receptor (Fc epsilon RI): from physiology to pathology. Annu Rev Immunol (1999) 17:931-72. doi:10.1146/annurev. immunol.17.1.931

39. Bieber T, de la Salle H, Wollenberg A, Hakimi J, Chizzonite R, Ring J, et al. Human epidermal Langerhans cells express the high affinity receptor for immunoglobulin E (Fc epsilon RI). J Exp Med (1992) 175(5):1285-90. doi:10.1084/jem.175.5.1285

40. Maurer D, Fiebiger E, Reininger B, Wolff-Winiski B, Jouvin MH, Kilgus O, et al. Expression of functional high affinity immunoglobulin $\mathrm{E}$ receptors (Fc epsilon RI) on monocytes of atopic individuals. J Exp Med (1994) 179(2):745-50. doi:10.1084/jem.179.2.745

41. Maurer D, Fiebiger S, Ebner C, Reininger B, Fischer GF, Wichlas S, et al. Peripheral blood dendritic cells express $\mathrm{Fc}$ epsilon RI as a complex composed of Fc epsilon RI alpha- and Fc epsilon RI gamma-chains and can use this receptor for IgE-mediated allergen presentation. J Immunol (1996) 157(2):607-16.

42. Tunon-De-Lara JM, Redington AE, Bradding P, Church MK, Hartley JA, Semper AE, et al. Dendritic cells in normal and asthmatic airways: expression of the alpha subunit of the high affinity immunoglobulin E receptor (Fc epsilon RIalpha). Clin Exp Allergy (1996) 26(6):648-55. doi:10.1046/j.1365-2222.1996. 1095481.x

43. Novak N, Allam JP, Hagemann T, Jenneck C, Laffer S, Valenta R, et al. Characterization of FcepsilonRI-bearing CD123 blood dendritic cell antigen-2 plasmacytoid dendritic cells in atopic dermatitis. J Allergy Clin Immunol (2004) 114(2):364-70. doi:10.1016/j.jaci.2004.05.038

44. Mudde GC, Van Reijsen FC, Boland GJ, de Gast GC, Bruijnzeel PL, BruijnzeelKoomen CA. Allergen presentation by epidermal Langerhans' cells from patients with atopic dermatitis is mediated by IgE. Immunology (1990) 69(3):335-41.
45. Bieber T. Fc epsilon RI on human epidermal Langerhans cells: an old receptor with new structure and functions. Int Arch Allergy Immunol (1997) 113(13):30-4. doi:10.1159/000237500

46. Maurer D, Ebner C, Reininger B, Fiebiger E, Kraft D, Kinet JP, et al. The high affinity IgE receptor (Fc epsilon RI) mediates IgE-dependent allergen presentation. J Immunol (1995) 154(12):6285-90.

47. Maurer D, Fiebiger E, Reininger B, Ebner C, Petzelbauer P, Shi GP, et al. Fc epsilon receptor I on dendritic cells delivers IgE-bound multivalent antigens into a cathepsin S-dependent pathway of MHC class II presentation. J Immunol (1998) 161(6):2731-9.

48. Sallmann E, Reininger B, Brandt S, Duschek N, Hoflehner E, GarnerSpitzer E, et al. High-affinity IgE receptors on dendritic cells exacerbate Th2-dependent inflammation. J Immunol (2011) 187(1):164-71. doi:10.4049/ jimmunol.1003392

49. Wigginton SJ, Furtado PB, Armour KL, Clark MR, Robins A, Emara M, et al. An immunoglobulin E-reactive chimeric human immunoglobulin G1 antiidiotype inhibits basophil degranulation through cross-linking of FcepsilonRI with FcgammaRIIb. Clin Exp Allergy (2008) 38(2):313-9. doi:10.1111/j.13652222.2007.02896.x

50. Nakamura A, Kubo T, Takai T. Fc receptor targeting in the treatment of allergy, autoimmune diseases and cancer. Adv Exp Med Biol (2008) 640:220-33. doi:10.1007/978-0-387-09789-3_17

51. Lee SE, Jeong SK, Lee SH. Protease and protease-activated receptor-2 signaling in the pathogenesis of atopic dermatitis. Yonsei Med J (2010) 51(6):808-22. doi:10.3349/ymj.2010.51.6.808

52. Arora P, Ricks TK, Trejo J. Protease-activated receptor signalling, endocytic sorting and dysregulation in cancer. J Cell Sci (2007) 120(Pt 6):921-8. doi:10.1242/jcs.03409

53. Steinhoff M, Corvera CU, Thoma MS, Kong W, McAlpine BE, Caughey $\mathrm{GH}$, et al. Proteinase-activated receptor-2 in human skin: tissue distribution and activation of keratinocytes by mast cell tryptase. Exp Dermatol (1999) 8(4):282-94. doi:10.1111/j.1600-0625.1999.tb00383.x

54. Rattenholl A, Steinhoff M. Proteinase-activated receptor-2 in the skin: receptor expression, activation and function during health and disease. Drug News Perspect (2008) 21(7):369-81. doi:10.1358/dnp.2008.21.7.1255294

55. Tomee JF, van Weissenbruch R, de Monchy JG, Kauffman HF. Interactions between inhalant allergen extracts and airway epithelial cells: effect on cytokine production and cell detachment. J Allergy Clin Immunol (1998) 102(1):75-85. doi:10.1016/S0091-6749(98)70057-0

56. King C, Brennan S, Thompson PJ, Stewart GA. Dust mite proteolytic allergens induce cytokine release from cultured airway epithelium. J Immunol (1998) 161(7):3645-51.

57. Kauffman HF, Tomee JF, van de Riet MA, Timmerman AJ, Borger P. Proteasedependent activation of epithelial cells by fungal allergens leads to morphologic changes and cytokine production. J Allergy Clin Immunol (2000) 105(6 Pt 1):1185-93. doi:10.1067/mai.2000.106210

58. Yu HS, Angkasekwinai P, Chang SH, Chung Y, Dong C. Protease allergens induce the expression of IL-25 via Erk and p38 MAPK pathway. J Korean Med Sci (2010) 25(6):829-34. doi:10.3346/jkms.2010.25.6.829

59. Kamijo S, Takeda H, Tokura T, Suzuki M, Inui K, Hara M, et al. IL-33-mediated innate response and adaptive immune cells contribute to maximum responses of protease allergen-induced allergic airway inflammation. J Immunol (2013) 190(9):4489-99. doi:10.4049/jimmunol.1201212

60. Sun G, Stacey MA, Schmidt M, Mori L, Mattoli S. Interaction of mite allergens Der $\mathrm{p} 3$ and Der $\mathrm{p} 9$ with protease-activated receptor- 2 expressed by lung epithelial cells. J Immunol (2001) 167(2):1014-21.

61. Asokananthan N, Graham PT, Stewart DJ, Bakker AJ, Eidne KA, Thompson $\mathrm{PJ}$, et al. House dust mite allergens induce proinflammatory cytokines from respiratory epithelial cells: the cysteine protease allergen, Der $\mathrm{p} 1$, activates protease-activated receptor (PAR)-2 and inactivates PAR-1. J Immunol (2002) 169(8):4572-8.

62. Adam E, Hansen KK, Astudillo Fernandez O, Coulon L, Bex F, Duhant X, et al. The house dust mite allergen Der p 1, unlike Der p 3, stimulates the expression of interleukin-8 in human airway epithelial cells via a proteinase-activated receptor-2-independent mechanism. J Biol Chem (2006) 281(11):6910-23. doi:10.1074/jbc.M507140200

63. Kauffman HF, Tamm M, Timmerman JA, Borger P. House dust mite major allergens Der $\mathrm{p} 1$ and Der $\mathrm{p} 5$ activate human airway-derived epithelial cells by 
protease-dependent and protease-independent mechanisms. Clin Mol Allergy (2006) 4:5. doi:10.1186/1476-7961-4-5

64. Page K, Strunk VS, Hershenson MB. Cockroach proteases increase IL-8 expression in human bronchial epithelial cells via activation of protease-activated receptor (PAR)-2 and extracellular-signal-regulated kinase. J Allergy Clin Immunol (2003) 112(6):1112-8. doi:10.1016/j.jaci.2003.08.050

65. Chiu LL, Perng DW, Yu CH, Su SN, Chow LP. Mold allergen, pen C 13, induces IL-8 expression in human airway epithelial cells by activating proteaseactivated receptor 1 and 2. J Immunol (2007) 178(8):5237-44.

66. Page K, Ledford JR, Zhou P, Dienger K, Wills-Karp M. Mucosal sensitization to German cockroach involves protease-activated receptor-2. Respir Res (2010) 11:62. doi:10.1186/1465-9921-11-62

67. Day SB, Ledford JR, Zhou P, Lewkowich IP, Page K. German cockroach proteases and protease-activated receptor- 2 regulate chemokine production and dendritic cell recruitment. J Innate Immun (2012) 4(1):100-10. doi:10.1159/ 000329132

68. Lee YC, Lee HB, Rhee YK, Song CH. The involvement of matrix metalloproteinase-9 in airway inflammation of patients with acute asthma. Clin Exp Allergy (2001) 31(10):1623-30. doi:10.1046/j.1365-2222.2001.01211.x

69. Kelly EA, Busse WW, Jarjour NN. Increased matrix metalloproteinase-9 in the airway after allergen challenge. Am J Respir Crit Care Med (2000) 162(3 Pt 1):1157-61. doi:10.1164/ajrccm.162.3.9908016

70. Page K, Hughes VS, Bennett GW, Wong HR. German cockroach proteases regulate matrix metalloproteinase-9 in human bronchial epithelial cells. Allergy (2006) 61(8):988-95. doi:10.1111/j.1398-9995.2006.01103.x

71. Ebeling C, Lam T, Gordon JR, Hollenberg MD, Vliagoftis H. Proteinaseactivated receptor- 2 promotes allergic sensitization to an inhaled antigen through a TNF-mediated pathway. J Immunol (2007) 179(5):2910-7.

72. Antony AB, Tepper RS, Mohammed KA. Cockroach extract antigen increases bronchial airway epithelial permeability. J Allergy Clin Immunol (2002) 110(4):589-95. doi:10.1067/mai.2002.127798

73. Capetandes A, Zhuang M, Haque FN, Xie L, Frieri M. Vascular endothelial growth factor is increased by human pulmonary cells stimulated with Dermatophagoides sp. extract. Allergy Asthma Proc (2007) 28(3):324-30. doi:10.2500/aap.2007.28.2999

74. Heijink IH, van Oosterhout A, Kapus A. Epidermal growth factor receptor signalling contributes to house dust mite-induced epithelial barrier dysfunction. Eur Respir J (2010) 36(5):1016-26. doi:10.1183/09031936.00125809

75. Shin SH, Lee YH, Jeon CH. Protease-dependent activation of nasal polyp epithelial cells by airborne fungi leads to migration of eosinophils and neutrophils. Acta Otolaryngol (2006) 126(12):1286-94. doi:10.1080/ 00016480500395179

76. Takeda K, Kaisho T, Akira S. Toll-like receptors. Annu Rev Immunol (2003) 21:335-76. doi:10.1146/annurev.immunol.21.120601.141126

77. Dabbagh K, Dahl ME, Stepick-Biek P, Lewis DB. Toll-like receptor 4 is required for optimal development of Th2 immune responses: role of dendritic cells. J Immunol (2002) 168(9):4524-30.

78. Hammad H, Chieppa M, Perros F, Willart MA, Germain RN, Lambrecht BN. House dust mite allergen induces asthma via Toll-like receptor 4 triggering of airway structural cells. Nat Med (2009) 15(4):410-6. doi:10.1038/nm.1946

79. Phipps S, Lam CE, Kaiko GE, Foo SY, Collison A, Mattes J, et al. Toll/IL-1 signaling is critical for house dust mite-specific helper T cell type 2 and type 17 [corrected] responses. Am J Respir Crit Care Med (2009) 179(10):883-93. doi:10.1164/rccm.200806-974OC

80. Tan AM, Chen HC, Pochard P, Eisenbarth SC, Herrick CA, Bottomly HK. TLR4 signaling in stromal cells is critical for the initiation of allergic Th2 responses to inhaled antigen. J Immunol (2010) 184(7):3535-44. doi:10.4049/jimmunol. 0900340

81. Noulin N, Quesniaux VF, Schnyder-Candrian S, Schnyder B, Maillet I, Robert T, et al. Both hemopoietic and resident cells are required for MyD88-dependent pulmonary inflammatory response to inhaled endotoxin. J Immunol (2005) 175(10):6861-9.

82. Piggott DA, Eisenbarth SC, Xu L, Constant SL, Huleatt JW, Herrick CA, et al. MyD88-dependent induction of allergic Th2 responses to intranasal antigen. J Clin Invest (2005) 115(2):459-67. doi:10.1172/JCI200522462

83. Poynter ME, Cloots R, van Woerkom T, Butnor KJ, Vacek P, Taatjes DJ, et al. NF-kappa B activation in airways modulates allergic inflammation but not hyperresponsiveness. J Immunol (2004) 173(11):7003-9.
84. Skerrett SJ, Liggitt HD, Hajjar AM, Ernst RK, Miller SI, Wilson CB. Respiratory epithelial cells regulate lung inflammation in response to inhaled endotoxin. Am J Physiol Lung Cell Mol Physiol (2004) 287(1):L143-52. doi:10.1152/ajplung.00030.2004

85. Sheller JR, Polosukhin VV, Mitchell D, Cheng DS, Peebles RS, Blackwell TS. Nuclear factor kappa B induction in airway epithelium increases lung inflammation in allergen-challenged mice. Exp Lung Res (2009) 35(10):883-95. doi:10.3109/01902140903019710

86. Ather JL, Hodgkins SR, Janssen-Heininger YM, Poynter ME. Airway epithelial NF-kappaB activation promotes allergic sensitization to an innocuous inhaled antigen. Am J Respir Cell Mol Biol (2011) 44(5):631-8. doi:10.1165/rcmb.20100106OC

87. Eisenbarth SC, Piggott DA, Huleatt JW, Visintin I, Herrick CA, Bottomly K. Lipopolysaccharide-enhanced, toll-like receptor 4-dependent $\mathrm{T}$ helper cell type 2 responses to inhaled antigen. J Exp Med (2002) 196(12):1645-51. doi: $10.1084 /$ jem. 20021340

88. Li DQ, Zhang L, Pflugfelder SC, De Paiva CS, Zhang X, Zhao G, et al. Short ragweed pollen triggers allergic inflammation through Toll-like receptor 4dependent thymic stromal lymphopoietin/OX40 ligand/OX40 signaling pathways. J Allergy Clin Immunol (2011) 128:1318.e-25.e. doi:10.1016/j.jaci.2011. 06.041

89. Sancho D, Reis e Sousa C. Signaling by myeloid C-type lectin receptors in immunity and homeostasis. Annu Rev Immunol (2012) 30:491-529. doi:10. 1146/annurev-immunol-031210-101352

90. Nathan AT, Peterson EA, Chakir J, Wills-Karp M. Innate immune responses of airway epithelium to house dust mite are mediated through beta-glucandependent pathways. JAllergy Clin Immunol (2009) 123(3):612-8. doi:10.1016/ j.jaci.2008.12.006

91. Brown GD, Herre J, Williams DL, Willment JA, Marshall AS, Gordon S. Dectin-1 mediates the biological effects of beta-glucans. J Exp Med (2003) 197(9):1119-24. doi:10.1084/jem.20021890

92. Al-Ghouleh A, Johal R, Sharquie IK, Emara M, Harrington H, Shakib F, et al. The glycosylation pattern of common allergens: the recognition and uptake of Der $\mathrm{p} 1$ by epithelial and dendritic cells is carbohydrate dependent. PLoS ONE (2012) 7(3):e33929. doi:10.1371/journal.pone.0033929

93. Reibman J, Hsu Y, Chen LC, Bleck B, Gordon T. Airway epithelial cells release MIP-3alpha/CCL20 in response to cytokines and ambient particulate matter. Am J Respir Cell Mol Biol (2003) 28(6):648-54. doi:10.1165/rcmb.2002$0095 \mathrm{OC}$

94. Pichavant M, Charbonnier AS, Taront S, Brichet A, Wallaert B, Pestel J, et al. Asthmatic bronchial epithelium activated by the proteolytic allergen Der $\mathrm{p} 1$ increases selective dendritic cell recruitment. J Allergy Clin Immunol (2005) 115(4):771-8. doi:10.1016/j.jaci.2004.11.043

95. Stumbles PA, Strickland DH, Pimm CL, Proksch SF, Marsh AM, McWilliam AS, et al. Regulation of dendritic cell recruitment into resting and inflamed airway epithelium: use of alternative chemokine receptors as a function of inducing stimulus. J Immunol (2001) 167(1):228-34.

96. Nolte MA, Leibundgut-Landmann S, Joffre O, Reis e Sousa C. Dendritic cell quiescence during systemic inflammation driven by LPS stimulation of radioresistant cells in vivo. J Exp Med (2007) 204(6):1487-501. doi:10.1084/jem. 20070325

97. Takai T. TSLP expression: cellular sources, triggers, and regulatory mechanisms. Allergol Int (2012) 61(1):3-17. doi:10.2332/allergolint.11-RAI-0395

98. Soumelis V, Reche PA, Kanzler H, Yuan W, Edward G, Homey B, et al. Human epithelial cells trigger dendritic cell mediated allergic inflammation by producing TSLP. Nat Immunol (2002) 3(7):673-80. doi:10.1038/ni805

99. Larson RP, Comeau MR, Ziegler SF. Cutting edge: allergen-specific CD4 T cells respond indirectly to thymic stromal lymphopoietin to promote allergic responses in the skin. JImmunol (2013) 190(9):4474-7. doi:10.4049/jimmunol. 1201677

100. Omori M, Ziegler S. Induction of IL-4 expression in CD4(+) T cells by thymic stromal lymphopoietin. J Immunol (2007) 178(3):1396-404.

101. Ito T, Wang YH, Duramad O, Hori T, Delespesse GJ, Watanabe N, et al. TSLPactivated dendritic cells induce an inflammatory $\mathrm{T}$ helper type 2 cell response through OX40 ligand. J Exp Med (2005) 202(9):1213-23. doi:10.1084/jem. 20051135

102. Watanabe N, Hanabuchi S, Marloie-Provost MA, Antonenko S, Liu YJ, Soumelis V. Human TSLP promotes CD40 ligand-induced IL-12 production by myeloid 
dendritic cells but maintains their Th2 priming potential. Blood (2005) 105(12):4749-51. doi:10.1182/blood-2004-09-3622

103. Wang YH, Ito T, Homey B, Watanabe N, Martin R, Barnes CJ, et al. Maintenance and polarization of human $\mathrm{TH} 2$ central memory $\mathrm{T}$ cells by thymic stromal lymphopoietin-activated dendritic cells. Immunity (2006) 24(6):827-38. doi:10.1016/j.immuni.2006.03.019

104. Kato A, Favoreto S Jr, Avila PC, Schleimer RP. TLR3- and Th2 cytokinedependent production of thymic stromal lymphopoietin in human airway epithelial cells. J Immunol (2007) 179(2):1080-7.

105. Allakhverdi Z, Comeau MR, Jessup HK, Yoon BR, Brewer A, Chartier S, et al. Thymic stromal lymphopoietin is released by human epithelial cells in response to microbes, trauma, or inflammation and potently activates mast cells. J Exp Med (2007) 204(2):253-8. doi:10.1084/jem.20062211

106. Lee HC, Ziegler SF. Inducible expression of the proallergic cytokine thymic stromal lymphopoietin in airway epithelial cells is controlled by NFkappaB. Proc Natl Acad Sci U S A (2007) 104(3):914-9. doi:10.1073/pnas.0607305104

107. Bleck B, Tse DB, Curotto de Lafaille MA, Zhang F, Reibman J. Diesel exhaust particle-exposed human bronchial epithelial cells induce dendritic cell maturation and polarization via thymic stromal lymphopoietin. J Clin Immunol (2008) 28(2):147-56. doi:10.1007/s10875-007-9149-0

108. Bleck B, Grunig G, Chiu A, Liu M, Gordon T, Kazeros A, et al. MicroRNA375 regulation of thymic stromal lymphopoietin by diesel exhaust particles and ambient particulate matter in human bronchial epithelial cells. J Immunol (2013) 190(7):3757-63. doi:10.4049/jimmunol.1201165

109. Kouzaki H, O’Grady SM, Lawrence CB, Kita H. Proteases induce production of thymic stromal lymphopoietin by airway epithelial cells through protease-activated receptor-2. J Immunol (2009) 183(2):1427-34. doi:10.4049/ jimmunol.0900904

110. Allakhverdi Z, Comeau MR, Smith DE, Toy D, Endam LM, Desrosiers M, et al. CD34+ hemopoietic progenitor cells are potent effectors of allergic inflammation. J Allergy Clin Immunol (2009) 123(2):472-8. doi:10.1016/j.jaci.2008.10. 022

111. Lei L, Zhang Y, Yao W, Kaplan MH, Zhou B. Thymic stromal lymphopoietin interferes with airway tolerance by suppressing the generation of antigenspecific regulatory T cells. J Immunol (2011) 186(4):2254-61. doi:10.4049/ jimmunol.1002503

112. Bogiatzi SI, Fernandez I, Bichet JC, Marloie-Provost MA, Volpe E, Sastre X, et al. Cutting Edge: Proinflammatory and Th2 cytokines synergize to induce thymic stromal lymphopoietin production by human skin keratinocytes. J Immunol (2007) 178(6):3373-7.

113. Kashyap M, Rochman Y, Spolski R, Samsel L, Leonard WJ. Thymic stromal lymphopoietin is produced by dendritic cells. J Immunol (2011) 187(3):1207-11. doi:10.4049/jimmunol.1100355

114. Al-Shami A, Spolski R, Kelly J, Keane-Myers A, Leonard WJ. A role for TSLP in the development of inflammation in an asthma model. J Exp Med (2005) 202(6):829-39. doi:10.1084/jem.20050199

115. Larson RP, Zimmerli SC, Comeau MR, Itano A, Omori M, Iseki M, et al. Dibutyl phthalate-induced thymic stromal lymphopoietin is required for Th2 contact hypersensitivity responses. J Immunol (2010) 184(6):2974-84. doi:10.4049/jimmunol.0803478
116. Yoo J, Omori M, Gyarmati D, Zhou B, Aye T, Brewer A, et al. Spontaneous atopic dermatitis in mice expressing an inducible thymic stromal lymphopoietin transgene specifically in the skin. J Exp Med (2005) 202(4):541-9. doi:10.1084/ jem.20041503

117. Zhou B, Comeau MR, De Smedt T, Liggitt HD, Dahl ME, Lewis DB, et al. Thymic stromal lymphopoietin as a key initiator of allergic airway inflammation in mice. Nat Immunol (2005) 6(10):1047-53. doi:10.1038/ni1247

118. Zheng X, Ma P, de Paiva CS, Cunningham MA, Hwang CS, Pflugfelder SC, et al. TSLP and downstream molecules in experimental mouse allergic conjunctivitis. Invest Ophthalmol Vis Sci (2010) 51(6):3076-82. doi:10.1167/ iovs.09-4122

119. Zhang F, Huang G, Hu B, Song Y, Shi Y. A soluble thymic stromal lymphopoietin (TSLP) antagonist, TSLPR-immunoglobulin, reduces the severity of allergic disease by regulating pulmonary dendritic cells. Clin Exp Immunol (2011) 164(2):256-64. doi:10.1111/j.1365-2249.2011.04328.x

120. Ying S, O'Connor B, Ratoff J, Meng Q, Mallett K, Cousins D, et al. Thymic stromal lymphopoietin expression is increased in asthmatic airways and correlates with expression of Th2-attracting chemokines and disease severity. J Immunol (2005) 174(12):8183-90.

121. Shamim Z, Muller K, Svejgaard A, Poulsen LK, Bodtger U, Ryder LP. Association between genetic polymorphisms in the human interleukin-7 receptor alpha-chain and inhalation allergy. Int J Immunogenet (2007) 34(3):149-51. doi:10.1111/j.1744-313X.2007.00657.x

122. Bunyavanich S, Melen E, Wilk JB, Granada M, Soto-Quiros ME, Avila L, et al. Thymic stromal lymphopoietin (TSLP) is associated with allergic rhinitis in children with asthma. Clin Mol Allergy (2011) 9:1. doi:10.1186/1476-79619-1

123. Harada M, Hirota T, Jodo AI, Hitomi Y, Sakashita M, Tsunoda T, et al. Thymic stromal lymphopoietin gene promoter polymorphisms are associated with susceptibility to bronchial asthma. Am J Respir Cell Mol Biol (2011) 44(6):787-93. doi:10.1165/rcmb.2009-04180C

Conflict of Interest Statement: The authors declare that the research was conducted in the absence of any commercial or financial relationships that could be construed as a potential conflict of interest.

Received: 29 August 2013; accepted: 21 October 2013; published online: 04 November 2013.

Citation: Salazar F and Ghaemmaghami AM (2013) Allergen recognition by innate immune cells: critical role of dendritic and epithelial cells. Front. Immunol. 4:356. doi: 10.3389/fimmu.2013.00356

This article was submitted to Immunotherapies and Vaccines, a section of the journal Frontiers in Immunology.

Copyright (C) 2013 Salazar and Ghaemmaghami. This is an open-access article distributed under the terms of the Creative Commons Attribution License (CC BY). The use, distribution or reproduction in other forums is permitted, provided the original author(s) or licensor are credited and that the original publication in this journal is cited, in accordance with accepted academic practice. No use, distribution or reproduction is permitted which does not comply with these terms. 